\title{
Preface: Understanding spatio-temporal variability of water resources and the implications for IWRM in semi-arid eastern and southern Africa
}

\author{
Hodson Makurira ${ }^{1}$, Dominic Mazvimavi ${ }^{2}$, Evison Kapangaziwiri ${ }^{3}$, Jean-Marie Kileshye Onema ${ }^{4}$, and \\ Webster Gumindoga ${ }^{1}$ \\ ${ }^{1}$ University of Zimbabwe, P.O. Box MP 167, Mt Pleasant, Harare, Zimbabwe \\ ${ }^{2}$ Department of Earth Sciences, University of the Western Cape, Private Bag X17, \\ Bellville, 7535 Cape Town, South Africa \\ ${ }^{3}$ CSIR NRE, Building 33, Room S222, 627 Meiring Naude Road, Brummeria, Pretoria 0184, South Africa \\ ${ }^{4}$ WaterNet, P.O. Box MP600, Mount Pleasant, Harare, Zimbabwe
}

Correspondence: Hodson Makurira (makurira@eng.uz.ac.zw)

Published: 29 May 2018

This Special Issue of the Proceedings of the International Hydrological Sciences (IAHS) is a compilation of selected papers that were presented at the IAHS Scientific Assembly held in Port Elizabeth, South Africa, from the 10 to 14 July 2017.

This volume contains 14 peer-reviewed papers that focus on integrated water resources management in the southern Africa region and are a culmination of extensive research in five broad themes, namely, (1) hydrological modelling (2) groundwater hydrology (3) application of earth observations in water resources assessments (4) water allocation and use and (5) water quality management. Southern Africa offers wide research opportunities to solve challenges related to the assessment of surface and groundwater resources, water supply and sanitation, water pollution and allocation. However, data scarcity and difficulty in accessing research sites discourage many research efforts. The papers in this Volume are research outputs from mainly postgraduate studies conducted at universities in southern Africa with the sole aim of contributing to knowledge in water sciences that will facilitate informed decision-making and policy formulation by water managers and practitioners in the region.
The editors wish to thank all the contributing authors for their efforts, Waternet which facilitated and funded the bulk of the research that is presented in this volume and the numerous reviewers who contributed to the production of quality papers. Special acknowledgement is also extended to IAHS for facilitating the participation of young scientists at the Scientific Assembly in Port Elizabeth. 